Proceedings of the Second Annual Forestry Symposium 1996: Management and Sustainable Utilization of Forest Resources, Sri Lanka, 6-7 December 1996. (Eds. Amarasekera, HS, Ranasinghe, D MS HK and Finlayson. W. Published by Department of Forestry and Environmental Science, University of Sri Jayewardenepura, Sri Lanka (1998)

\title{
QUALITY MEASUREMENTS IN CLOUD WATER, RAIN, THROUGHFALL, AND STREAM WATER, AT HORTON PLAINS
}

\author{
R.P.R.U. Rajapaksha', E.R.N. Gunawardena', \\ K.A. Nandasena ${ }^{2}$ and P.T.W. Rosier ${ }^{3}$ \\ ${ }^{1}$ Department of Agricultural Engineering, University of Peradeniya \\ ${ }^{2}$ Department of Soil Science, University of Pcradeniya \\ ${ }^{3}$ Institute of Hydrology, Wallingford, UK
}

\begin{abstract}
Die-back of natural forests in the Horton Plains has been of some concern in recent times. One of the possible causes is atmospheric pollution. Since clouds (jog) carry greater amounts of pollutants than rain, an assessment was made of both rain and cloud water quality, as well as that of throughfall and stream water. Samples were collected and analysed at weekly intervals from November 199.5 to May 1996. They were tested for pH, electrical conductivity (EC), nitrate nitrogen $\left(\mathrm{NO}_{3}-\mathrm{N}\right)$, ammonium nitrogen $\left(\mathrm{NH}_{4}-\mathrm{N}\right)$ and sulphate sulphur $\left(\mathrm{SO}_{4}-\mathrm{S}\right)$. Plastic buckets were used to collect rain water and throughfall. A collector was designed and constructed to collect cloud water. The average $\mathrm{pH}$ of cloud water was 5.0 and the values as low as 3.9 was observed during certain periods.. According to the literature, this latter high acidity could be injurious, burning tender leaves. The highest concentrations of $\mathrm{NO}_{3}-\mathrm{N}, \mathrm{NH}_{4}-\mathrm{N}$, and $\mathrm{SO}_{4}-\mathrm{S}$ in cloud water were 10.23, 5.04 and $9.40 \mathrm{mg} /$ itre respectively; very much higher than those of the rain water. These pollutant levels and high acidity may cause stress on the plants. The concentration of chemicals is also high in the throughfall. However, the soil acts as a buffer and provides good quality water to the streams, as shown by the very low concentration of chemicals there.
\end{abstract}

\section{Introduction}

In Sri Lanka. most attention has been given in the past to water quantity, rather than quality. However, quality has also become important, mainly because of industrialization and the intensification of agriculture. As a consequence of the establishment of free-trade zones in Katunayake, Biyagama, and Koggala, and of industries elsewhere in the country, emissions of some undesirable gases, such as carbon dioxide, carbon monoxide, sulphur dioxode. and nitrogen dioxide would likely to be increased. In addition, the rapid increase of motor vehicles in the last two decades has also added considerable amounts of undesirable gases to the atmosphere. More industrialized countries emit greater quantities of pollutants. However, pollution in other countries may also have some influence on Sri Lanka, since there are no boundaries as far as the environment is concerned. 
An important indicator of environmental pollution is the quality of the rain water. Rain is naturally acid with a pH of 5.6 to 6.0 (National Research Council, 1981). "Acid rain", with lower $\mathrm{pH}$, is mainly due to the solution of various gases and particles emitted by industries. The environmental effects attributed to acid rain are mainly adverse; they include damage to lakes, streams, groundwater, forests, agriculture, and human health.

The Horton Plains is one of the most important watersheds in Sri Lanka, from which tributaries of three major rivers originate: the Malaweli, Kelani and Walawe. Water quality changes in this area will have serious implications for the water resources of the country. Dieback of natural forests in the Horton Plains has also been a concern among scientists in recent times. Atmospheric pollution is a possible cause of this problem.

It has becn shown elscwhere that the amount of pollutants in clouds or fog is substantially greater than in rain water. Since the Horton Plains is in the cloud-forest zone, it is important to monitor the quality of cloud water here as well as that of rain water.

There have been no previous studies in Sri Lanka of atmospheric water quality, and therefore the present study, to quantify hydrogen ion concentration $(\mathrm{pH})$, electrical conductivity (EC), nitrate nitrogen $\left(\mathrm{NO}_{3}-\mathrm{N}\right)$. ammonium nitrogen $\left(\mathrm{NH}_{4}-\mathrm{N}\right)$, and sulphate sulphur $\left(\mathrm{SO}_{4}-\mathrm{S}\right)$ in rain water, cloud water, throughfall, and stream water will establish a baseline for future studies.

\section{Study site}

\section{Study site and methods}

The Horton Plains are at the eastern edge of the wet zone, at $2100 \mathrm{~m}$. The meteorological station has an annual average rainfall of $2050 \mathrm{~mm}$ (Bastable \& Gunawardana, 1994). The site forms part of an extensive. undulating plateau which supports $8 \%$ (3160 ha) of Sri Lanka's remaining natural montane forest and grassland. Weather conditions are dominated by continuous and at times gale-strength winds, with persistent clond cover.

\section{Collection of water samples}

Rainfall. cloud water. throughfall, and stream water samples were collected from Horton Plains at weekly intervals from November 1995 to May 1996. Plastic buckets were placed on the existing high tower and under trees to collect rainfall and throughfall respectively. They were also used to take water from a stream. A cloud-water collector was designed and constructed (Fig. 1): it was made only from plastic and glass to prevent metallic contamination. It was installed on the tower, at $20 \mathrm{~m}$ above ground level.

All samples were transferred to polythene bags and brought to Peradeniya for analysis. Samples were $\mathrm{kept}$ in the deep-freezer at $-18^{\circ} \mathrm{C}$, until the analyses were made.

\section{Rainfall and wind data}

Data on the quantity and time of rainfall and on wind direction from November 1995 to May 1996 were obtained from the Horton Plains meteorological station. 


\section{Analysis of water samples}

The $\mathrm{pH}$ and electrical conductivity (EC) of the water samples were measured by standard $\mathrm{pH}$ and conductivity meters. Chemical analyses were made to quantify $\mathrm{NO}_{3}-\mathrm{N}$ (Bremner, 1965) and $\mathrm{NH}_{4}-\mathrm{N}$ (Page, 1982) by colorimetric methods. A turbidimetric method was used to determine $\mathrm{SO}_{4}-\mathrm{S}$ (Hoeff et al., 1973).

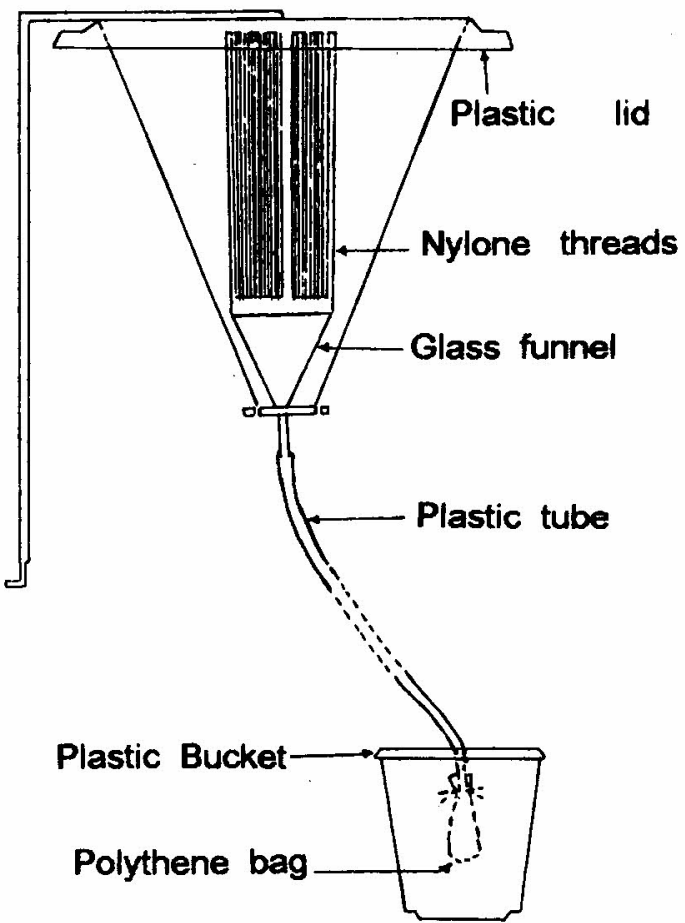

Figure 1: Cloud water collector

Results and discussion

The following table summarizes the results:

Table 1: Average values and ranges of water quality parameters at Horton Plains

\begin{tabular}{llllll}
\hline & $\mathbf{p H}$ & $\mathbf{E C}(\mathbf{m S / c m}$ & $\begin{array}{l}\text { NO-N } \\
(\mathbf{m g} / \mathbf{l i t r e})\end{array}$ & $\begin{array}{l}\mathbf{N H}_{\mathbf{4}}-\mathbf{N} \\
(\mathbf{m g} / \mathbf{l i t r e})\end{array}$ & $\begin{array}{l}\text { SO4-S } \\
\text { (mg/litre) }\end{array}$ \\
\hline Stream water & $6.05-7.45$ & $0.0-0.01$ & $0.0-1.37$ & $0.0-0.32$ & $0.0-3.80$ \\
Rain water & $5.37-7.47$ & $0.0-0.08$ & $0.0-3.05$ & $0.17-2.38$ & $0.0-3.37$ \\
Through fall & $6.46-7.57$ & $0.0-0.18$ & $0.0-5.2$ & $0.05-11.44$ & $0.52-26.6$ \\
Cloud water* & $\mathbf{3 . 8 8 - 5 . 5 9}$ & $0.0-0.20$ & $1.13-16.2$ & $0.05-5.09$ & $1.05-9.40$ \\
\hline
\end{tabular}

* Values are for the period from February to May 1996 
Rain water

Fig. 2 shows the water-quality data for rain collected at Horton Plains from the first week of November 1995 to the last week of April 1996. The pH varied between 5.8 and 7.5 with an average of 6.5. The typical range of $\mathrm{pH}$ for rain water is between 5.6 and 6.8 (National Research Council). In this experiment three samples out of sixteen had a pH of more than 7.0. These three samples also had a relatively high concentration of $\mathrm{NH}_{4}-\mathrm{N}$. One possible explanation is that free ammonia in the air or in the clouds can react with $\mathrm{OH}^{-}$ions to form $\mathrm{NH}_{4} \mathrm{OH}$.

The $\mathrm{SO}_{4}-\mathrm{S}$ content of the rain water samples varied from 0.19 to 3.37 , with an average of $1.28 \mathrm{mg} /$ litre. The average $\mathrm{NO}_{3}-\mathrm{N}$ concentration was $0.52 \mathrm{mg} /$ litre. The average $\mathrm{NO}_{3}-\mathrm{N}$ concentration was $0.52 \mathrm{mg} / \mathrm{litre}$, ranging from a trace to 3.05. The presence of $\mathrm{SO}_{4}-\mathrm{S}$ and $\mathrm{NO}_{3}-\mathrm{N}$ indicates pollution. However, the amounts of total dissolved electrolytes or ions in the rain water samples are very low, as is also shown by the very low EC.

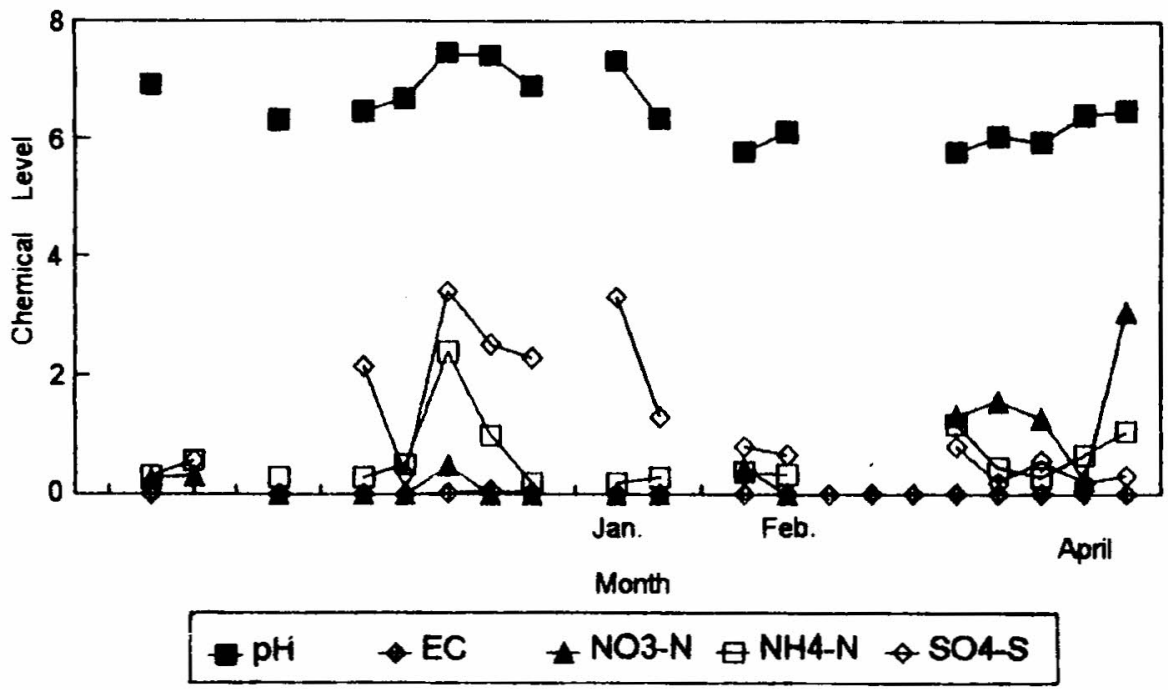

Figure 2: Quality of rain water

Fig. 4 shows the $\mathrm{NO}_{3}-\mathrm{N}, \mathrm{NH}_{4}-\mathrm{N}, \mathrm{SO}_{4}-\mathrm{S}, \mathrm{pH}$, and $\mathrm{EC}$ of the cloud-water samples collected from mid- February to May 1996. The $\mathrm{pH}$ ranged from 5.6 to 3.9 with an average of 5.0. The $\mathrm{NO}_{3}-\mathrm{N}$ concentration varied from a trace to $10.23 \mathrm{mg} /$ litre. The average concentration of $\mathrm{NH}_{4}-\mathrm{N}$ was $1.32 \mathrm{mg} /$, with a range of 0.05 to 5.09 . The average concentration of $\mathrm{SO}_{4}-\mathrm{S}$ was $4.05 \mathrm{mg} / \mathrm{litre}$, with a range from 1.05 to 9.40 .

The average values of all the chemical parameters of cloud water were considerably higher than those of rain. The hydrogen ion concentration was 35 times higher. The average concentrations of $\mathrm{NO}_{3}-\mathrm{N}, \mathrm{NH}_{4}-\mathrm{N}$ and $\mathrm{SO}_{4}-\mathrm{S}$ were respectively about 8,2 , and 3 times higher. This indicates that the risk of acid precipitation is greater from cloud water than from rainfall. The high levels of acidic conditions can cause adverse effects on trees 


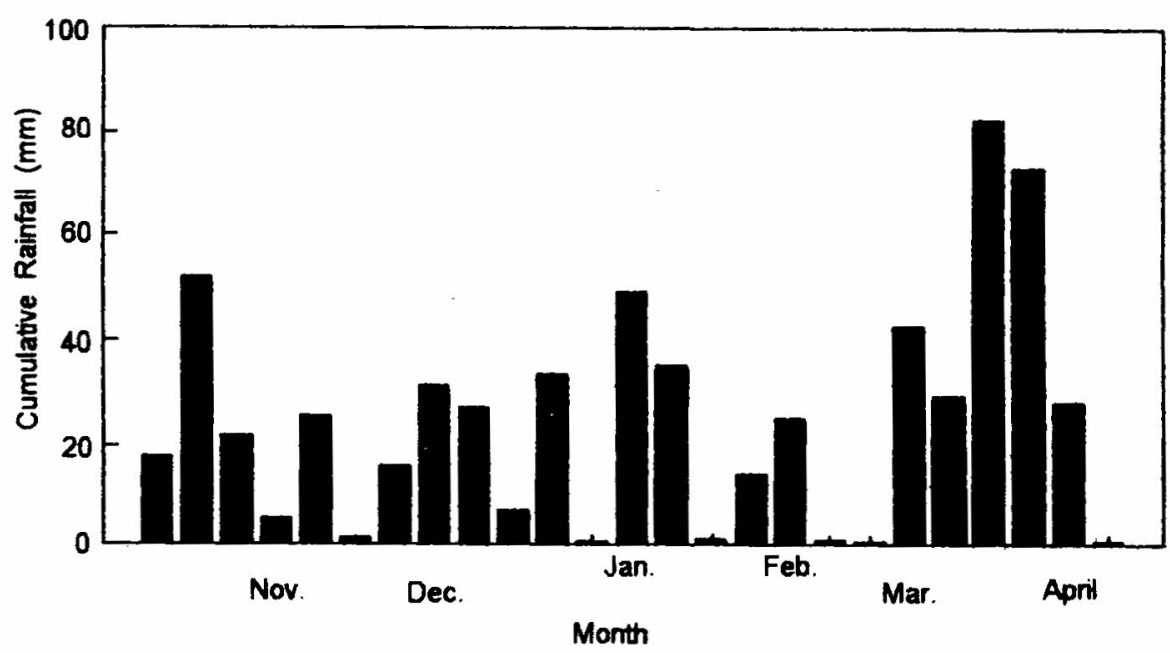

Figure 3 : Cumulative Rainfall Cloud water

The higher concentration of chemicals in clouds compared to rain is probably due to the large specific surface area of the cloud droplets. Raindrops have an average diameter of $0.5 \mathrm{~mm}$, whereas cloud droplets fall within the range of 0.001 to $0.1 \mathrm{~mm}$. More chemicals can adhere to the surface of cloud droplets than to raindrops of the same volume.

With regard to the severity of the adverse effects on trees, individual events with very high acidity are more important than high average acidity over a long period. The lowest $\mathrm{pH}$ recorded during the experiment was 3.9. The sample was collected during the first week of May. There was hardly any rainfall during this week. Since this is the average $\mathrm{pH}$ value of a cumulative sample, it is safe to assume that there were clouds with even lower $\mathrm{pH}$ values. This finding could have serious implications for the montane cloud forests.

In Horton Plains, $0.8 \%$ of the total forest has been destroyed in the past because of die-back (Balasubramaniam et al., undated). Reasons for the die-back have not yet been found. In view of the results obtained from this study it cannot be ruled out that the die-back condition is due to high concentrations of acids in the clouds. Perhaps some other factor, such as water stress, may be responsible for die-back, along with high acidity. It will be difficult to draw firm conclusions from this study until more detailed studies of the die-back condition are carried out.

\section{Throughfall}

Fig. 5 shows the variation of the different water quality parameters of the throughfall with time. The $\mathrm{pH}$ of the throughfall varied from 6.5 to 7.6, with an average of 7.0. The average

\section{8}


$\mathrm{NH}_{1}-\mathrm{N}, \mathrm{SO}_{4}-\mathrm{S}$ and $\mathrm{NO}_{3}-\mathrm{N}$ concentrations were respectively $1.71,6.34$, and $1.09 \mathrm{mg} / \mathrm{litre}$. ic, 5,3 , and 2 limes higher than in rain.

One reason for the higher concentration of chemicals in the throughfall may be dry deposition of gases or particulate malter on the vegetation. Hainy and granular plant surfaces, especially of the lichens that are attached to the tree stems and branches, could trap matter suspended in the form of dry or wet acrosols. Throughfall will wash these contaminants from the vegetation. Another possibility is the release of excess nutrients from the plants through the stomata.

As in the cases of rainfall and cloud water, throughfall showed peak concentrations of chemicals at the end of March and the begimning of April. For example, the concentration of $\mathrm{SO}_{4}-\mathrm{S}$ increased to 22 and $26 \mathrm{mg} /$ litre during these two periods respectively.

\section{Streame water}

Changes in the water quality in the stream at Horton Plain are shown in Fig. 6. The water in the stream is fairly neutral, as shown by pH values from 6.9 to 7.4 , with an average of 6.9 . The EC varied from 0.0 to $0.1 \mathrm{mS} / \mathrm{cm}$, indicating that there were hardly any dissolved ions in the stream. The average values of $\mathrm{SO}_{4}-\mathrm{S}, \mathrm{NH}_{4}-\mathrm{N}$ and $\mathrm{NO}_{3}-\mathrm{N}$ were 0.92. 0.17, and 0.36 $\mathrm{mg} /$ litre. The buffering action of soils with high Cation Exchange Capacity is one of the main reasons for the presence of lower concentration of ions in stream water (Kalpage and Thenabadu, 1969). However the trend of chemical concentration with time closely follows that for rain, cloud water, and throughfall.

\section{Conclusions}

- Horton Plains are unlikely to cxperience acid rain as such, as is indicated by the low valucs of acidity. $\mathrm{EC}$, and chemical concentrations.

- However, the concentrations of chemicals in cloud water and in throughfall are higher than in rain water, and the high pollutant contents of cloud water can caluse stress to plants.

- The stream at Horton Plains shows no evidence of pollution. 


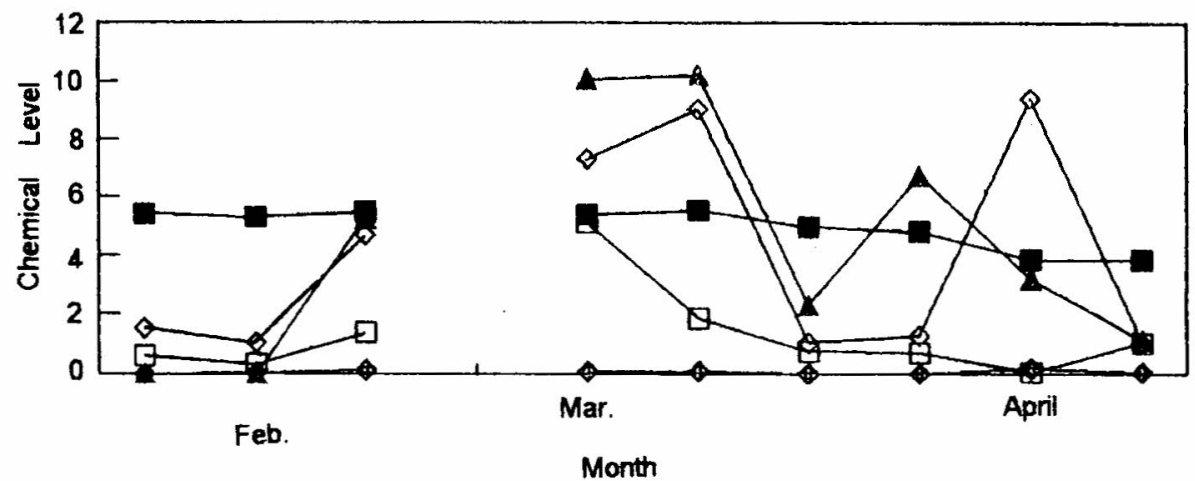

Figure 4 - Quality of cloud water

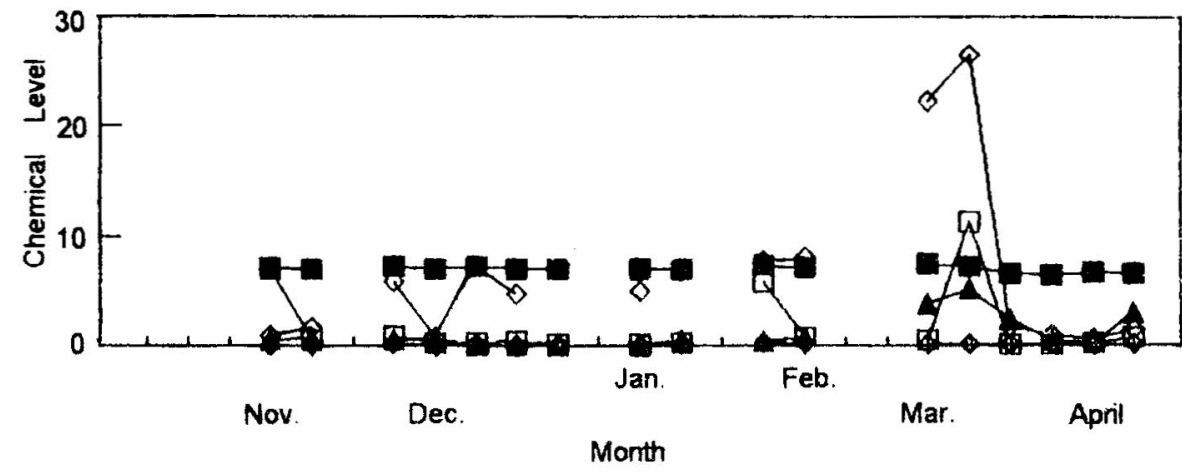

Figure 5 : Quality of throughfall

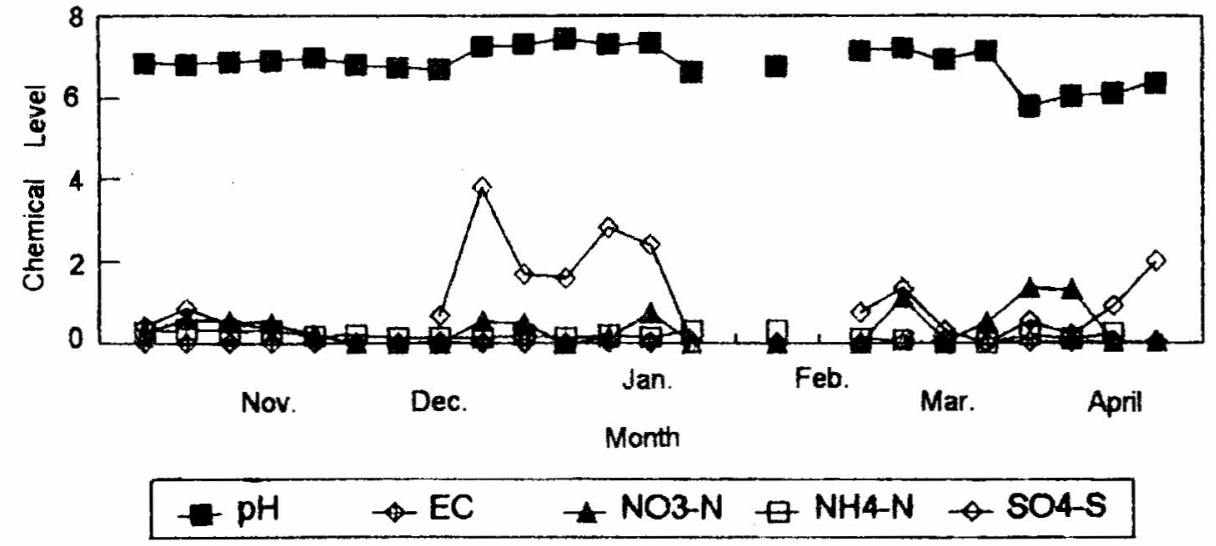

Figure 6: Quality of stream water 


\section{References}

Balasubramaniam, S. Ratnayake. S. and White, R. (undated). ODA Upper Mahaweli Catchment Develop-ment Unit.

Bastable. H.G. and Gunawardana, E.R.N. (1995). A comparison of climate between two sites of different elevation in Sri Lanka. Institute of Hydrology. Wallingford. UK.

Bremner J.M. (1965). Inorganic forms of nitrogen. In Black. C.A et al. (Eds.) Methods of soil analysis, Part 2. Agronomy 9, 1179-1237.

Hoeff, R.G. Walsh, L.M. and. Keeney, D.R (1973) Evaluation of various experiments for available soil sulfur. Soil Science Society of America Proceedings 37, 401-404.

Kalpage. F.S.C.P and Thenabadu. M.W.(1969) Some characteristics of the high organic matter content of montane soils in the wet zone. Tropical Agriculturist. Vol CXXV, $51-63$.

National Research Council (1981) Atmosphere-biosphere interaction: towards a better understanding of the ecological consequences of fossil fuel combustion. National Research Council, National Academy Press, Washington DC.

Page, P.L (1982). Chemical and microbial properties. In Methods of soil analysis, Part 2, 2nd ed. American Society of Agronomists, Madison, Wisconsin. Pp.674-675. 